Lebedeva, G.N. (2020). Philosophy of cultural heritage: scientific and public organizations of the Russian Empire. Eurasia: Current Issues of Cultural Heritage. European Scientific e-Journal, 3(3), 43-52. Hlučín-Bobrovníky: "Anisiia Tomanek" OSVČ.

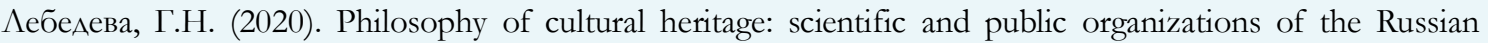
Empire. Eurasia: Current Issues of Cultural Heritage. European Scientific e-Journal, 3(3), 43-52. Hlučín-Bobrovníky: "Anisiia Tomanek" OSVČ.

DOI: $10.47451 /$ her2020-12-001

The paper is published in Crossref, ICI Copernic, BASE, Zenodo, OpenAIRE, LORY, HSLU, J-Gate, Academic Resource Index ResearchBib, ISI International Scientific Indexing, eLibrary, Mendeley, and WebArchive databases.

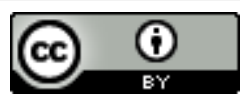

Galina N. Lebedeva, Associate Professor, Candidate of Philosophical Sciences (PhD), Department of Philosophy, Leningrad State University. St. Petersburg, Russia.

\title{
Philosophy of cultural heritage: scientific and public organizations of the Russian Empire
}

Abstract: Cultural processes of globalisation affect not only the life of an individual, group or professional corporations, but also affect the internal social and economic sphere of any civilization or community, changing even complex and entrenched social institutions. The author considers the philosophical foundations of cultural heritage preservation in the Russian Empire in the first half of the 19th century. The article traces how the scientific and practical activities of Russian statesmen and scientists have shaped programs and institutions for the preservation of cultural heritage. The author concludes that cultural heritage is used to determine the organisation of society. In general, culture, as a factor of social change, preserves both customs, established forms of behavior regulation, and new but not always dynamic factors and values. The main function of cultural heritage is to maintain national memory and stability in the life of the people.

Keywords: S.G. Stroganov, F.I. Buslaev, cultural heritage as an activity, social movements and scientific organizations, mobilization of private resources, Imperial Moscow Society of Russian History and Antiquities, Society of Old Russian Art Lovers, synthetic discipline on folk culture.

Галина Николаевна Аебедева, к. филос. н., доцент кафелры, кафедра философии, Аенинградский государственный университет имени А.С. Пушкина. Санкт-Петербург, Россия.

\section{Фимософия культурного наследия: научные и общественные организации Российской империи}

Аннотачия: Культурные процессы глобализации влияют не только на жизнь отАельного человека, группы или профессиональных корпораций, но также влияют на внутреннюю социальную и экономическую сферу мюбой цивилизации или сообщества, изменяя Ааже сложные и укоренившиеся социальные институты. Рассмотрены философские основания Аеятельности по сохранению культурного наследия в Российской империи в первой половине XIX века. В статье удалось проследить, как научная и практическая деятельность российских государственных Аеятелей и ученых сформировали программы и учреждения по сохранению культурного наследия. Автор Аелает заключение, что культурное наследие используется Аля определения организации общества. В целом культура как фактор социальных изменений сохраняет как 
обычаи, устоявшиеся формы регулирования поведения, так и новые, но не всегда Аинамические факторы и ценности. Основная функция культурного наследия заключается в сохранении национальной памяти и стабильности в жизни народа.

Ключевъе слова: С.Г. Строганов, Ф.И. Буслаев, культурное наследие как Аеятельность, общественные Авижения и научные организации; мобилизация частных ресурсов; Императорское Московское Общество Истории и Аревностей Российских; Общество Аюбителей Аревнерусского искусства, синтетическая дисциплина о народной культуре.

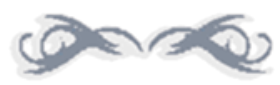

\section{Introduction}

Cultural processes of globalization affect not only the life of an individual, group or professional corporations, but also affect the internal social and economic sphere of any civilization or community, changing even complex and entrenched social institutions.

Despite the fact that the concept of "civilization" appeared in the 18th century, it still has many interpretations due to the competition of various philosophical schools, the diversity of the formation of civilizations in history. In addition, some civilizations have disappeared on their own, or are undergoing changes under the influence of globalisation. This is why it is important to preserve endangered historical monuments. Even the philosophers of the $18^{\text {th }}$ century noticed both positive and negative lessons of the consequences of the mutual influence of cultures. The idea of a universal human civilization, on the one hand, defined the meaning of progress, which is seen as uniform and unified. There are special and pragmatic means of measuring progress: scientific and technological achievements, often understood one-sidedly. And success and effective management are seen as universal. To do this, we can abandon traditions and national identity, and the right of peoples to self-determination. On the other hand, this leads to the fact that the uniqueness of cultures is either denied under the pretext of the processes of domestic and international politics, the economy and social sphere of all societies without exception, or it is declared about universal values and the need to form similar institutions, such as democracy and the market. Unwillingness to take into account local traditions and customs as not very appropriate to the spirit of the time, often leads to conflicts.

1.

O. Spengler described the life cycles of civilizations. S. Huntington, G. Hofstede, G. Ternborn wrote about local civilizations, their values, and the tradition. Every culture and civilization have its own heritage and past. The concept of "cultural heritage" has been widely used since the 1980s, emphasizing the connection in time. As modern researchers I.I. Gorlova and A.L. Zorin write, the concept of "cultural heritage" is used to express continuity, "meaning, first, the act of receiving and transmitting something from one generation to another, i.e., from one generation to another denotes the continuity of generations in the historical process" (Gorlova et al., 2018). Serious work is being done in special institutions, a classification of problems and areas related to their study is defined and adopted, and both theoretical and applied issues are highlighted. As V.N. Rastorguev writes, "Research on the study of heritage requires not only fixing and saving, but also measures for organisation, systematisation and 
institutionalisation, not to mention resource and legal support" (Rastorguev, 2018). At the international level, UNESCO adopted a Resolution in 1989. "Recommendation on the preservation of traditional culture and folklore", according to which States are recommended to take measures for the preservation, dissemination and protection of heritage (Collection of legal acts, 2003).

Preservation of the content of language and culture as a heritage also requires attention. Identifying heritage only with monuments of material culture and with positive values from the past, it is necessary to remember the achievements of the spoken word. Language, values, traditions, customs, as well as painting, are cultural heritage. This approach is undergoing a new modification, and as D. Munieri writes, "Cultural heritage appeals to us through the values that people assign to it, so there is no other way to understand and interpret the material only through the tangible." (Munjeri, 2007)

In Russia, the understanding and preservation of heritage was defined long before international programs and commissions. The leading feature of historiosophy was the desire to comprehend and preserve the past, which helped to realize the future in a new way. The practical and scientific activities of Russian statesmen and officials, aristocrats and patrons of art, scientists, philologists, philosophers, as well as the experience of organisers of cultural heritage preservation show that many such programs operated initially without such a self-designation.

This coincided with an increase in the importance of reason and science, which gained even greater authority under the influence of Enlightenment philosophy. Also, "the educational programme of Catherine II considered the ordering of the education system, the development of publishing and library business, scientific thought and artistic creativity" (Kagan, 1996). In general, the end of the $18^{\text {th }}$ century shows an unprecedented rise in Russian national culture, the importance of literature increases, and new writers' names appear. The Experience of the Historical Dictionary of Russian Writers by N.I. Novikov (1772) contains information about 250 writers. From 1762 to 1800, 78 periodicals were published in Russian and foreign languages. They helped to get acquainted with foreign scientific organisations, and information about them began to be published in Russia. At this time, developing musical and theatrical culture, with the support of the government there is a big work in urban planning, expanding the Academy of Fine Arts, organised the first in the Russian State Museum of Fine Arts - the Hermitage, set up the new scholars' society, e.g., the Free Economic Society (1765). There are various organisations, many of which have worked for a long time, engaged in scientific or research activities, e.g., the Moscow Society of Agriculture, founded in 1820. All of them popularised knowledge in economy, in which the government was also interested. With the goal to bring together interested people, such organisations have contributed to the development of the consciousness and culture of both individuals and society as a whole. This is how group interests and meanings were purposefully formed. The general activity involved stimulated the development of both the individual and the group, and a common experience was formed. This has facilitated the mobility of members of these groups and organisations both at the community level and beyond, at the level of representation in society as a whole. Informal communication channels co-existed at the same time, which were then repeated. Thus, a kind of mobilisation of private resources took place, without which individual activity would have been dispersed. 


\section{2.}

The interest in the national heritage was not only a reaction to the beginning and inevitable processes of industrialisation or nostalgia for the idealisation of the past. John Stuart Mill also emphasised that "the idea of comparing the present with the past could only become popular when everyone realised that they were living in a changing world." With the changing present, the study of the past provided a vision of what the future prospects are. The emerging fans of antiquity emphasised the connection with antiquity through literary monuments and language learning. At the turn of the $18^{\text {th }}$ and $19^{\text {th }}$ centuries, the interest in folklore was noted. It can be noted as the initial period of collecting and searching. Many outstanding researchers have distinguished themselves in this field (and none of them was a professional scientist). For example, the archaeographer and historian A.I. Musin-Pushkin, famous for the discovery of "Words about Igor's Regiment". Archaist philologist A.S. Shishkov, became one of the founders of the society of lovers of Russian literature in 1811 (Lebedeva, 2018). N.P. Rumyantsev, became the first organiser of the study of antiquities, his collection of books and manuscripts became the basis of his museum, which received his name. Russian Slavophiles (Khomyakov, Samarin, Danilevsky) concluded that there were separate regional civilizations. Western philosophy, represented by S. Huntington, agreed with this opinion a century and a half later.

Perhaps the first institution that turned to the study of folk heritage was the Society of Russian history and antiquities (OIDR), founded in 1804 at Moscow University. The first results of the work were modest, publications were irregular, and it was suspended in 1810, but the awakening of interest in the study of heritage was laid. At the same time, voluntary associations became active in the study of history: agricultural, economic, literary, and general academic communities and organisations. The Russian Geographical Society, founded in 1846, aimed not only to study the riches of Russia and its peoples. A special ethnographic Department was created (K.M. Baer, K.D. Kavelin, N. Nadezhin, I.I. Sreznevsky) to collect folk Chronicles. In General, the details of the organisation and activities of the RGS are described in detail.

With the aim of collecting and publishing, the written monuments, and folk poetry was established "Archeological Commission". In 1834, the Members of the Commission published the "Complete Collection of Russian annals", "historical Acts", "Acts of law", cadastres, appeared a series of "Russian historical library". All this served as the basis for historicallinguistic and historical-literary research. Study of myths-how to reconstruct epics and fairy tales, epics in Russia began: M.D. Chulkov, M.I. Popov, A.S. Kaisarov. Academician F.I. Buslaev, the Creator of the comparative-historical method in the study of literature and epics, believed that in myths one can find the origin and development of those principles that determine the national worldview (Balandin, 1988; Lebedeva, 2018).

From the very beginning, scientific societies did not become opposition to the state. Since this was a Patriotic matter and formed national pride, the tasks of such associations coincided with the tasks of the government. Most of the associations were under the August highest patronage. Often crowned heads themselves were at the origins of such societies. For example, the Royal Society in England, the Antiquarian College in Sweden, the Kunstkammer in Denmark-where historical objects were collected. 
When public statesmen are involved, a different situation arises. Their administrative activities, capabilities, and resources have an impact on the emergence of new institutions necessary for the state, or the formation of certain scientific disciplines, and in general on the formation of new directions.

Rare and unique cultural monuments (especially paintings, manuscripts, etc.) were of interest not only as rare but also as witnesses of history. "Representatives of the aristocratic circles were most involved in research related to cultural heritage and thus 'infected' the broad social strata with antiquity. The exceptional status of the monument as a unique cultural value determined the high social or even political prestige of its owner, contributed to the legitimization and exaltation of its power. The glorification of a nation's cultural heritage has always been used to shape its national consciousness and identity. Mythology played a large role (and continues to play) with its heroes and legends, outstanding historical events, which used to construct symbols that become means of state representation" (Gorlova et al., 2018).

\section{4.}

During the period of strengthening the official Imperial course under Nicholas I and the search for ideology, the supreme power recognised the importance of monitoring the training of personnel for the civil service. On the eve of changes and approval of the new University Charter in 1835, count Sergei Grigoryevich Stroganov (1794-1882) was appointed Trustee of the Moscow school district. The rector of the University was under the control of the Trustee of the school district, the position of the Trustee was approved by the emperor himself. The Trustee was a kind of "Boss of the University" who lived in the same city where the University is located, watched over how the professors performed their duties. The Trustees of the school district remained official executive officers and did not have an independent voice in the Ministry of public education. This was the third generation of Trustees, they were more independent personally, as they came from influential families and respected rights and freedoms. According to Uvarov, the titled elite could increase the prestige and status of universities. Also, they were required to have a scientific outlook, respect for scientific work, and, ideally, respect for scientific research itself. The Trustees had the task of encouraging and developing scientific research. S.G. Stroganov, financially independent, not concerned with personal career issues, enlightened, believed that the main task in society is education, and he was well educated. Historians estimate that the success of Moscow University was the result of Stroganov's ability to attract and organize the work of specialists, they were trained in European universities and educational institutions. And in the lives of some students, he played a very big role. Stroganov had a large library, a collection of icons, ancient coins, was well versed in art, founded a school of painting in Moscow, published a book about the Dmitrievsky Cathedral in Vladimir on Klyazma. As a patron of art, Stroganov became famous with his own money for opening the Stroganov school, where many artists and architects were trained in arts and crafts. Stroganov initiated the creation of the Society of Russian History and Antiquities at the Moscow University, where he was chairman (18371874). However, the publication of one of the collections resulted in Stroganov's removal from the position of Trustee. It was an essay by the British Ambassador to Moscow in the 16th century in the reign of Ivan IV, John Fletcher, the publication caused dissatisfaction with Minister Uvarov, who detailed his opinion, and all the persons were punished. By the Emperor's order, 
Stroganov was reprimanded, after which he resigned and was in disgrace until the end of his reign.

\section{5.}

One of these outstanding graduates of the University was Fyodor Ivanovich Buslaev (18181897), a linguist, folklorist, and academic. Buslaev's legacy is so extensive and at the same time relevant, a whole series of studies were published on memorable dates (Buslaev, 1897; Ky2lasova, 1985; Smirnov, 1978; Churmaeva, 1984).

After graduating from the University in 1838, Buslaev was assigned as a teacher in the second Moscow gymnasium but soon left this position, because the Trustee of the school district, S.G. Stroganov, invited him to the position of a home teacher. Almost immediately, Stroganov suggested that Buslaev goes on a trip abroad to give lessons to children (from spring, 1839 till April, 1841). For two years, still very young, at the age of 20-22, Buslaev visited the cities of Austria, Germany (Lübeck, Hamburg, Leipzig, Dresden) and Italy (Naples, Rome), where he was able to visit museums and aroused interest in the history of art, and he got acquainted with archeology, art history (Buslaev, 1897). These impressions contributed to the development of aesthetic taste, expanded its perception of the world, and horizons. Here he begins to study not only the history of Western European literature, early Italian painting, and the Italian language. Much of what I saw and thought about in Italy was later included in research on European art. To see the originals of art, the personal example of S.G. Stroganov himself, all this determined the range of topics. Buslaev's work On the Russian Facial Apocalypse is dedicated to the memory of the count.

In Italy, Buslaev reads Dante, and later in Moscow - a special course about Dante. He met with the head of the department of Latin manuscripts in the Vatican library, was engaged, and had a good command of the Italian language. I visited one of the most ancient - the Kircheerian Museum, where Roman antiquities, especially, Etruscan, and a collection of ancient Roman coins were collected. Acquaintance with the Russians who lived in Italy at that time did not pass without a trace. This was the artist Alexander Ivanov, who was in his workshops, a friend from the University - Vasily Ivanovich Panov, in whose apartment Gogol lived. The result of thinking after direct impressions in Italy was in the future a lot of research Buslaev: these are topics of the comparative study of Byzantine and Russian art, about the canons of Byzantine art.

In 1865, he founded the Society of Lovers of Ancient Art at the Rumyantsev Museum (called the Museum society). In 1866, the General Concepts of Russian Icon-Painting was published. The ways of development of Russian and Western European art were 'sharply opposed' there (The Great Soviet Encyclopedia, 1951). He was constantly involved in the works of the Society of Ancient Russian Art, founded in 1865, was a member of the Commission for the organization of the Russian Department at the Paris exhibition in 1867, was the Chairman of the OLRS (18741877).

As M.V. Novikov and Perfilova write, Buslaev "was the first to create courses on the history of world literature, the history of Christian and Western European medieval art. Having a special attraction to the deep layers of the human psyche-the sphere of the collective unconscious, mythological thinking, and the spiritual practices and behavioural reactions generated by it, he was the first in our country to start restoring the world picture of archaic (pre-written) and 
ancient societies." (Lebedeva, 2018) After the organisational activity of Buslaev at the Paris exhibition of 1867, the world has developed an interest in Russian art.

Buslaev's student, Ws. Miller wrote in memory of the teacher that he created "the contours of a synthetic discipline about folk culture, which combined elements of folklore, linguistics, ethnography, the science of Slavic antiquities, comparative mythology, and art studies" (Novikov \& Perfilova, 2016).

\section{Conclusion}

Thus, the heritage of culture performs not only the tasks to familiarise with the beautiful, or forms a person. Cultural heritage is used to determine the organisation of society. In general, culture, as a factor of social change, preserves both customs, established forms of behaviour regulation, and new but not always dynamic factors and values. The main function of cultural heritage is to maintain national memory and stability in the life of the people.

Regulation of activities, personal acts, examples from the personal life of state and public figures and scientists contributed to the regulation and establishment of a management mechanism in new areas of activity, including the study and preservation of cultural heritage.

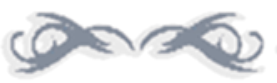

\section{References:}

Balandin, A. I. (1988). Mythological school in Russian folklore. Moscow: Nauka.

Buslaev, F. I. (1897). My memoirs. Voronezh: Central Chernozem Publishing House.

Buslaev, F. I. (1897). Russian heroic epic. Russian folk epic. Voronezh: Central Chernozem Publishing House.

Churmaeva, N. V. (1984). F.I. Buslaev: a book for students. Moscow: Prosveschenie.

Collection of legal acts of the Council of Europe on the preservation of cultural heritage. Part 2. (2003). Yekaterinburg: Bank of Cultural Information.

Gorlova, I. I., Kovalenko, T. V., \& Zorin, A. L. (2018). On the correlation of the concepts of "cultural heritage" and "cultural monuments" in the context of different historical epochs. Cultural Heritage of Russia, 4.

Kagan, M. S. (1996). Grad Petrov in the history of Russian culture. St. Petersburg.

Kyzlasova, I. L. (1985). History of the study of Byzantine and old Russian art in Russia (F.N. Buslaev, N.P. Kondakov: methods, ideas, theories). Moscow: MSU.

Lebedeva, G. N. (2018). At the origins of the philosophy of language in Russia: Shishkov on language as a collective memory of the people. Bulletin of the Leningrad State University, 3, 2.

Miller, Ws. (1898). In memory of Fyodor Ivanovich Buslaev. Moscow.

Munjeri, D. (2007). Tangible and intangible Heritage: from Difference to Convergence. Cultural Heritage. Critical Concepts in Media and Cultural Studies, 4. London: Routledge.

Novikov, M. V., \&Perfilova, T. B. (2016). Intellectual challenges of the 30-60s of the 19th century in F.I. Buslaev's scientific reflections. Yaroslavl Pedagogical Bulletin, 1.

Rastorguev, V. N. (2018). Civilizational heritage of Russia: methodology of the research program and contours of a long-term strategy. Materials of the all-Russian Conference the Civilizational 
Path of Russia: Cultural and Historical Heritage and Development Strategy. Journal of the Heritage Institute, 2.

Smirnov, S. V. (1978). Fyodor Ivanovich Buslaev. Moscow: MSU.

The Great Soviet Encyclopedia. (1951). 3rd ed. Vol. 6. Moscow. 